\title{
Algorithm for catalytic processes multicriteria optimization solution stability analysis to small perturbations in the parameters, through the kinetic model *
}

\author{
K.F. Koledina ${ }^{1,2}$, S.N. Koledin ${ }^{2}$, I.M. Gubaydullin ${ }^{1,2 * *}$ \\ ${ }^{1}$ Institute of Petrochemistry and Catalysis of RAS, Ufa, Russian Federation \\ ${ }^{2}$ Ufa State Petroleum Technological University, Ufa, Russian Federation
}

The multicriteria complex catalytic reactions optimal control based on the kinetic model is relevant for both industrial and laboratory processes. It is necessary to determine the stability radius for each parameter, for the chemical kinetics problems in the analysis of multicriteria optimization stability, with the aim of possible change in the calculated values with a given error.

The multicriteria optimization problem statement (MCO) for the catalytic reaction based on the kinetic model is presented. The solution stability definition of the MCO problem and the stability radius is given.

An algorithm has been developed for calculating the stability radius of the MCO problem solution. The problem of the MCO conditions was solved on the kinetic model basis for the catalytic reaction of primary amines methylation with dimethyl carbonate, and the acceptable range of changes in the optimal temperature and reaction time was calculated to prevent a strong change in the optimality criteria values.

The multicriteria complex catalytic reactions optimal control based on the kinetic model is relevant for both industrial and laboratory processes. However, only the all effective trajectories calculation, the varied parameters values and optimality criteria is insufficient. For the application in practice of the calculated modes for decision makers (DM), information on the acceptable interval for changing the optimal modes is important. In this work, for the catalytic reaction of methylation of primary amines with dimethyl carbonate, the problem of the MCO conditions was carried out on the basis of the kinetic model and the allowable range of changes in the optimal temperature and reaction time was calculated to prevent a strong change in the values of the optimality criteria.

Keywords: multicriteria optimization, algorithm for calculating the stability radius, effective trajectories, optimality criteria, variable parameters, perturbation matrix, amine methylation reaction.

Introduction. The necessity to study the optimization problems stability to some of their parameters perturbations is caused by a number of factors, such as the initial data inaccuracy, inadequacy of models to real processes, the numerical methods error, rounding errors, the necessity to develop algorithms for solving «close» problems, etc. It is impossible to correctly solve an arbitrary optimization problem without investigating its stability. In addition, for complex catalytic processes, technological operating conditions require the determination of allowable ranges of parameter values that ensure the stability of the calculated solution with an allowable error.

\footnotetext{
* This research was performed due to the Russian Science Foundation grant (project No. 19-71-00006, p. 2,3), partial financial support for the RFBR grant № 18-07-00341.

** E-mail: koledinakamila@mail.ru, koledinsrg@gmail.com, IrekMars@mail.ru.
} 
In [1], the general formulation and multicriteria trajectory problems stability solution is studied. We study the stability type of the problem to independent input data perturbations for which new effective solutions do not appear. The formula for calculating the stability radius of the problem is determined, and the necessary and sufficient stability conditions are indicated [1]. For the problems of chemical kinetics, when analyzing the multicriteria optimization stability, it is necessary to determine the stability radius for each parameter, with the aim of possible change in the calculated values with the given error.

Materials and methods. The multicriteria optimization (MCO) problem statement for the catalytic reaction based on the kinetic model has the form $[2,3]$ : find

$$
\underset{X \in D_{X}}{\max } F(X)=F(A)=T_{s}^{n}(A),
$$

where $X=\left(x_{1}, \quad x_{2}, \quad x_{3}, \quad x_{4}, \quad \ldots, \quad x_{m}\right)$ is the vector of variable parameters; $x_{1} \in\left[x_{1}^{-}, x_{1}^{+}\right] ; x_{2} \in\left[x_{2}^{-}, x_{2}^{+}\right] ; x_{3} \in\left[x_{3}^{-}, x_{3}^{+}\right] ; x_{4} \in\left[x_{4}^{-}, x_{4}^{+}\right] ; \ldots ; x_{m} \in\left[x_{m}^{-}, x_{m}^{+}\right] ;$are the direct restrictions on variable parameters forming the range of permissible values of variable parameters $D_{X}$; $F(X)=\left(f_{1}(X), f_{2}(X), f_{3}(X), \ldots f_{n}(X)\right)$ is the optimality criteria vector function; $A$ is the matrix of optimal values of variable parameters $A=\left(a_{i j}\right) \in R^{s \times m} ; m$ is the number of parameters, $s$ is the power of many solutions to the problem of $\mathrm{MCO} ; T_{s}^{n}(A)$ are the calculated $s$ values of $n$ optimality criteria or $s$ effective trajectories [1].

In (1), the maximum vector of the optimality criteria $F$ function is indicated. However, in the general case, the family of $n$ optimality criteria is defined by introducing a strict preference binary relation on the set of trajectories $T \Omega_{s}^{n}(A)$ [1]. This binary relation defines many paths $T_{s}^{n}(A)$ :

$$
T_{s}^{n}(A)=\left\{t^{\prime} \in T \mid t^{\prime} \Omega_{s}^{n}(A) t\right\}
$$

where $t^{\prime}$ is the effective trajectory from the set $T, t$ is some trajectory from the set $T$.

The solution of the MCO problem of the conditions for the catalytic reaction (1), (2) is denoted as $Z_{s}^{n}(A)$. Then it is necessary to determine the stability $Z_{s}^{n}(A)$.

The stable equilibrium state of the system according to Lyapunov means that with a sufficiently small deviation from the equilibrium position, the system will never go far from a singular point [4].

Then the problem $Z_{s}^{n}(A)$ is stable in the case when, for small independent perturbations of the elements of the matrix $A$, the values of the set of $s$-efficient trajectories deviate from the initial state by a small amount.

By analogy with $[5,6]$, the determination of the stability of the solution of the MCO problem $Z_{s}^{n}(A)$ looks as follows: if $B=\left(b_{i j}\right) \in R^{s \times m}$ is the perturbation matrix to A and given an arbitrarily small positive $\varepsilon$, one can always find such $\delta$ that:

$$
\forall \varepsilon>0 B: \max \left|b_{i j}\right|<\varepsilon \Rightarrow\left|T_{s}^{n}(A)-T_{s}^{n}(A+B)\right| \leq \delta .
$$

In accordance with $[5,6]$, the stability radius of the problem $Z_{s}^{n}(A)$ is defined as 


$$
\rho_{s}^{n}(A)=\left\{\begin{array}{l}
\sup P(A), \text { if } P(A) \neq ? \\
0, \text { if } P(A)=?
\end{array},\right.
$$

where $P(A)=\left\{\varepsilon>0 \mid\left(B: \max \left|b_{i j}\right|<\varepsilon \Rightarrow\left|T_{s}^{n}(A)-T_{s}^{n}(A+B)\right| \leq \delta\right)\right\}$.

Thus, the MCO problem $Z_{s}^{n}(A)$ is stable if and only if $\rho_{s}^{n}(A)>0$ [1].

The study results. According to the MCO problem conditions stability definition for carrying out catalytic reactions based on the kinetic model (1)-(4), the algorithm for calculating the stability radius of the problem is shown in Fig. 1.

The input data are the MCO problem calculated values $Z_{s}^{n}(A)$ is the matrix of optimal values of the varied parameters $A$, effective trajectories $T_{s}^{n}(A)$, the permissible changes values in the calculated trajectories $\delta$, the perturbation matrix $B$. The stability radius is determined for each variable parameter, based on the determination of the stability of the solution to the MCO problem (3).

The object of the study is the catalytic reaction of methylation of primary amines with dimethyl carbonate (DMC) in the presence of zeolite catalysts. The DMC reaction with the formation of mono-, dimethylanilines is of interest to industry, since $\mathrm{N}$-methylaniline is widely used as a raw material in the chemical, pharmaceutical and paint and varnish industries, and is also used as an additive in the manufacture of rubbers, synthetic rubbers, explosives and pyroxylin powder stabilizers. According to the literature [7], the direction of the reaction of primary aromatic amines with dimethyl carbonate depends on the nature of the catalyst. In the presence of type $\mathrm{Y}$ zeolite catalysts, N-methylation of aromatic amines is observed. Based on literature [7], field experimental data, a detailed scheme of chemical reactions of the reaction in the form of elementary stages is proposed. The reaction contains 6 irreversible steps in which 13 substances are involved (Z-zeolite catalyst). The starting reagents are aniline and dimethyl carbonate, and the output products are methylaniline and dimethylaniline. Kinetic parameters are described that describe the experimental data and correspond to the physicochemical nature of the process (table 1).

Table 1. Kinetic parameters of the reaction of methylation of primary amines with dimethyl carbonate $([\operatorname{lnk} 0]=[1 /(\mathrm{mol} * \min )],[\mathrm{Ej}]=[\mathrm{kcal} / \mathrm{mol}])$

\begin{tabular}{|l|l|l|}
\hline Stages & lnk0 & $\mathbf{E}_{\mathbf{j}}$ \\
\hline 1) $\mathrm{ArNH}_{2}+\left(\mathrm{CH}_{3} \mathrm{O}\right)_{2} \mathrm{CO} \rightarrow \mathrm{ArNHCO}_{2} \mathrm{CH}_{3}+\mathrm{CH}_{3} \mathrm{OH}$, & 11,2 & 13,5 \\
\hline 2) $\mathrm{ArNHCO}_{2} \mathrm{CH}_{3}+\mathrm{Z} \rightarrow \mathrm{ArNCO}_{2} \mathrm{CH}_{3}+\mathrm{HZ}$ & 10,8 & 7,9 \\
\hline $\begin{array}{l}\text { 3) } \mathrm{ArNCO}_{2} \mathrm{CH}_{3}+\left(\mathrm{CH}_{3} \mathrm{O}\right)_{2} \mathrm{CO} \rightarrow \mathrm{ArN}\left(\mathrm{CH}_{3}\right) \mathrm{CO}_{2} \mathrm{CH}_{3}+ \\
\mathrm{OCO}_{2},\end{array}$ & 9,8 & 7,7 \\
\hline 4) $\mathrm{CH}_{3} \mathrm{OCO}_{2}+\mathrm{HZ} \rightarrow \mathrm{CH}_{3} \mathrm{OH}+\mathrm{CO}_{2}+\mathrm{Z}$ & 21,5 & 19,6 \\
\hline 5) $\mathrm{ArN}_{\left(\mathrm{CH}_{3}\right) \mathrm{CO}_{2} \mathrm{CH}_{3}+\mathrm{CH}_{3} \mathrm{OH} \rightarrow \mathrm{ArNHCH}_{3}+\left(\mathrm{CH}_{3} \mathrm{O}\right)_{2} \mathrm{CO}}$ & 11,4 & 10,7 \\
\hline 6) $\mathrm{ArNHCH}+\mathrm{CH}_{3} \mathrm{OH} \rightarrow \mathrm{ArN}\left(\mathrm{CH}_{3}\right)_{2}+\mathrm{H}_{2} \mathrm{O}$ & 3,54 & 7,6 \\
\hline
\end{tabular}




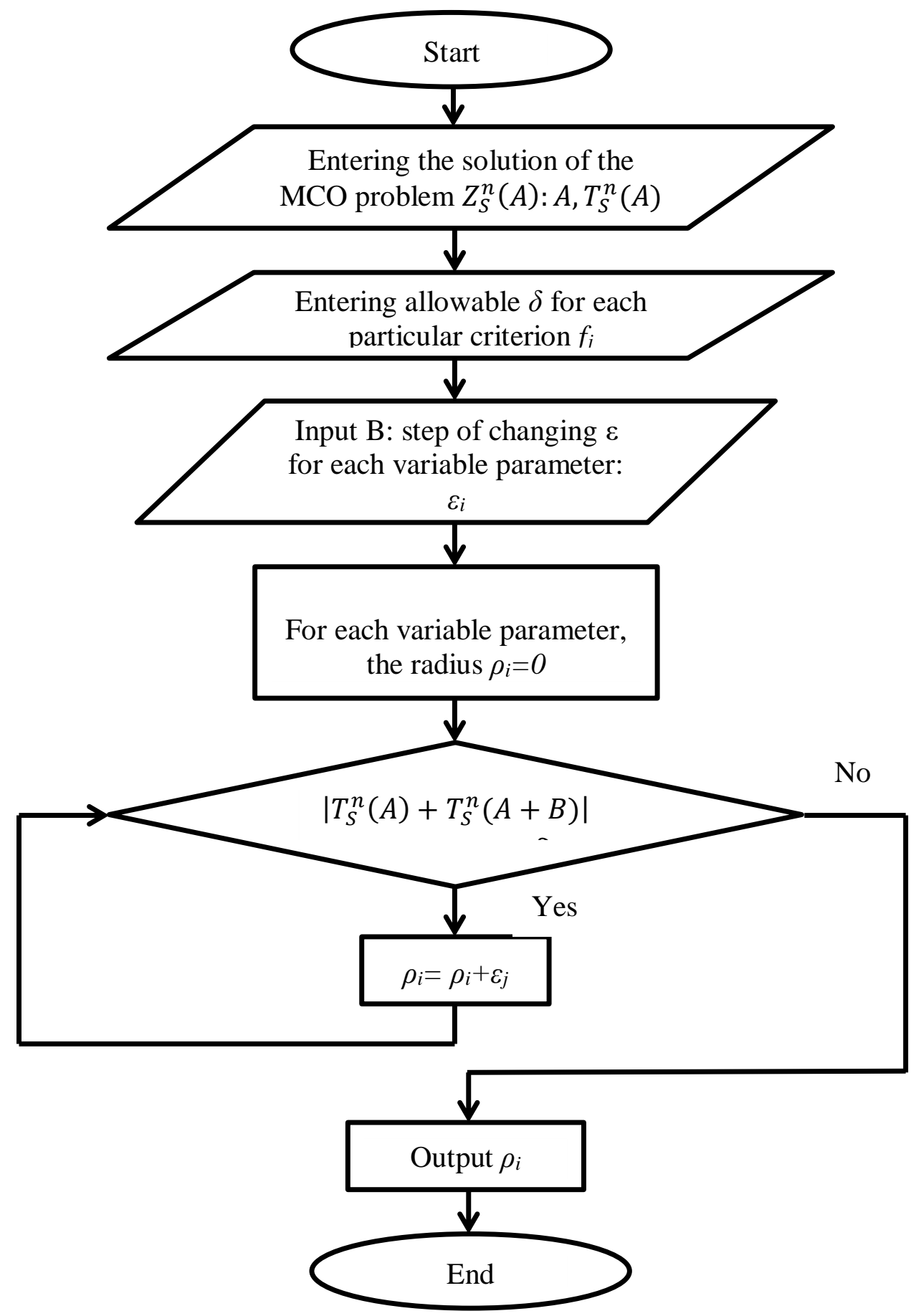

Fig. 1. The block diagram of the algorithm for calculating the MCO problem solution stability radius

For the reaction of methylation of primary amines with dimethyl carbonate in the presence of zeolite catalysts with multicriteria optimization, the optimality criteria are: maximizing the yield of products: methylaniline $\left(\mathrm{ArNHCH}_{3}\right)$ and dimethylaniline $\left(\mathrm{ArN}\left(\mathrm{CH}_{3}\right)_{2}\right)$. The reaction temperature $\mathrm{T}$, ${ }^{\circ} \mathrm{C}$ and the reaction time $\mathrm{t}$, min, are used as variable parameters. 
The solution of the MCO problem of the conditions for the catalytic reaction of methylation of primary amines with dimethyl carbonate was carried out in a previously developed informationcomputing system [8], by the Pareto approximation algorithm NSGA-II [9, 10].

Fig. 2 shows the Pareto front approximation is a unimprovable values set in the optimality criteria field. According to the scheme of chemical transformations shown in table 1, methylaniline is formed in stage 5 and, then, reacting with methanol, is converted to dimethylaniline in stage 6. Therefore, the criteria for maximizing the yield of methylaniline and dimethylaniline products are contradictory. An increase in the yield of one of them leads to a decrease in the yield of the other, which corresponds to the results of multicriteria optimization shown in Fig. 2.

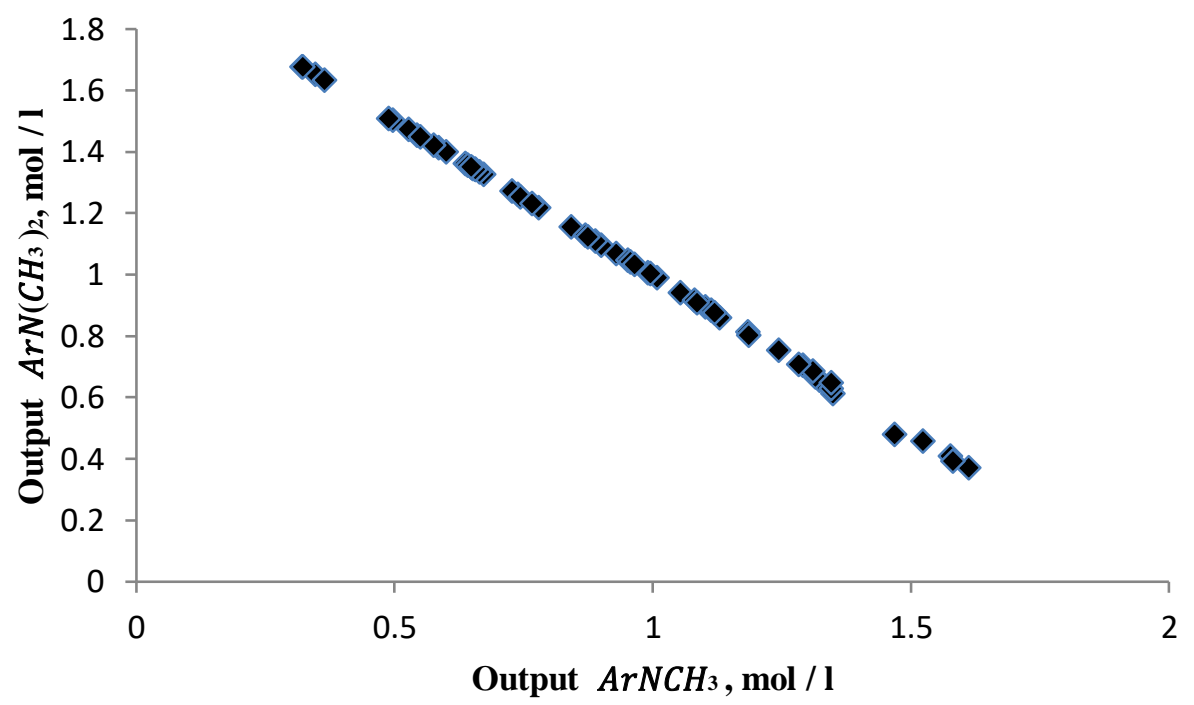

Fig. 2. Approximation of the Pareto front MCO problem of the primary amines with dimethyl carbonate methylation reaction

Fig. 3 shows the approximation of the Pareto set are the values corresponding to the Pareto front in the range of variable parameters.

The coordinates of each point in the graph of Fig. 2 correspond to the optimal values of the optimality criteria of Fig. 3. The temperature value ranges from 120 to $200^{\circ} \mathrm{C}$, the reaction time up to 400 minutes

Thus, to obtain the MCO problem solution of the reaction of methylation of primary amines with dimethyl carbonate, it is necessary to evaluate the stability and calculate the stability radius, which would allow the decision maker to evaluate the necessary technical conditions for the process.

When determining the values of permissible changes in the calculated trajectories $\delta$ (Fig. 2), we put no more than $10 \%$ for each optimality criterion (yield of methylaniline and dimethylaniline). Perturbations are set for varying parameters - temperature and reaction time. The stability radius is determined for each variable parameter, according to the algorithm in Fig. 1. Then a permissible change in the reaction temperature, not leading to large changes in the calculated values of the product yields, is $3^{\circ} \mathrm{C}$, and the allowable change in the optimal values of the reaction time is not more than 6 minutes. 


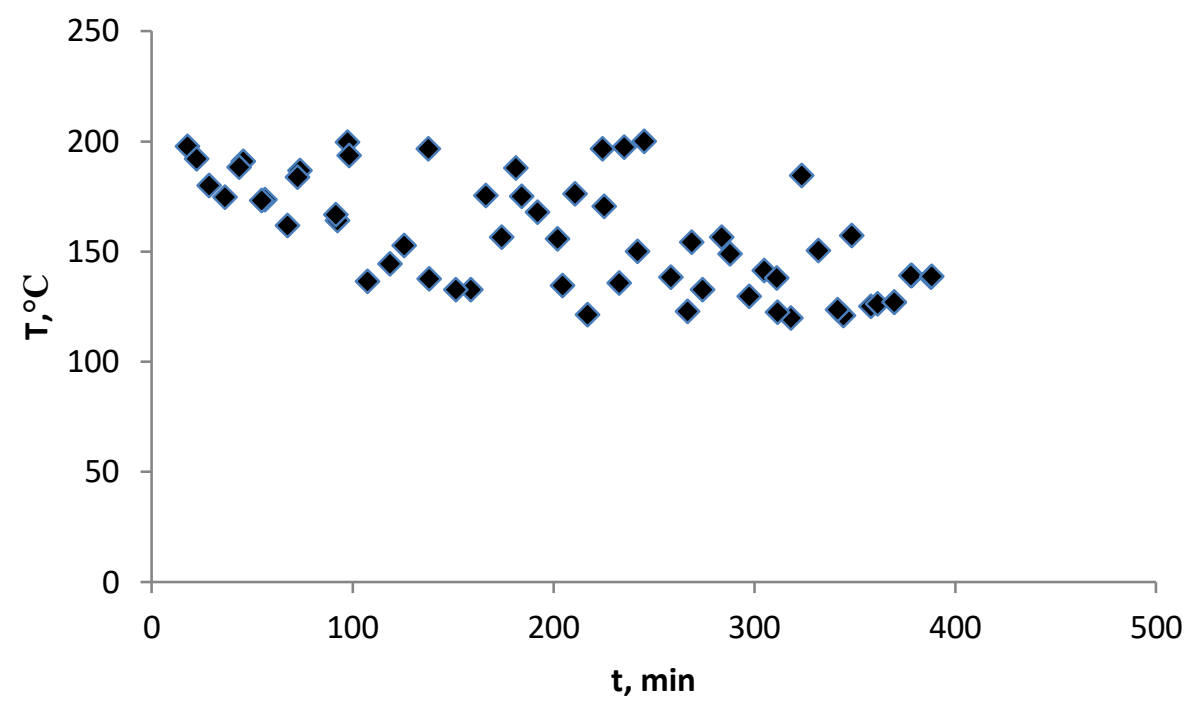

Fig. 3. Approximation of the Pareto set of the MCO problem of the reaction of methylation of primary amines with dimethyl carbonate

Conclusion. The multicriteria optimal control of complex catalytic reactions based on the kinetic model is relevant for both industrial and laboratory processes. However, only the calculation of all effective trajectories, values of the varied parameters and optimality criteria is insufficient. For the practical application of the calculated modes for the decision-maker, information on the acceptable interval of variation of the optimal modes is important. In this work, for the catalytic reaction of methylation of primary amines with dimethyl carbonate, the problem of the MCO conditions was carried out on the basis of the kinetic model and the allowable range of changes in the optimal temperature and reaction time was calculated to prevent a strong change in the values of the optimality criteria. The developed algorithm for calculating the stability radius of the solution of the MCO problem will be used to analyze other catalytic processes, including industrial ones [11-13].

\section{References}

1. Bukhtoyarov S.E. Parametrization of the optimality principle («from Pareto to Slater») and the stability of multicriteria trajectory problems / S. E. Bukhtoyarov, V. A. Emelichev // Diskretn. analysis and research. - 2003. - Vol. 10. - No. 2. - pp. 3-18.

2. Koledina K.F. Multi-objective optimization of chemical reaction conditions based on a kinetic model / K. F. Koledina, S. N. Koledin, A. P. Karpenko, I. M. Gubaydullin, M. K. Vovdenko // Journal of Mathematical Chemistry February. - 2019. - Vol. 57, Is. 2. - pp. 484-493

3. Koledina K.F. Internal Parallelism of Multi-objective Optimization and Optimal Control Based on a Compact Kinetic Model for the Catalytic Reaction of Dimethyl Carbonate with Alcohols / K.F. Koledina, S.N. Koledin, L.F. Nurislamova, I.M. Gubaydullin // In: Sokolinsky L., Zymbler M. (eds) Parallel Computational Technologies. PCT 2019. Communications in Computer and Information Science. - V. 1063. Springer, Cham.- pp. 242-255.

4. Pushkareva T.P. Mathematical modeling of chemical processes: a training manual / T.P. Pushkareva, A.V. Peregudov // Krasnoyarsk. state ped un-t them. V.P. Astafieva. Ed. 2nd stereotype. Krasnoyarsk, 2013. - 116 p. 
5. Emelichev V.A. Stability and regularization of vector problems of integer linear programming / V.A. Emelichev, E. Girlich, Yu.V. Nikulin, D.P. Podkopaev // Optimization. - 2002. - V. 51. - № 4. - pp. 645-676.

6. Emelichev V. A. Stability and regularization of vector problems of integer linear programming / V. A. Emelichev., D. P. Podkopaev // Diskret.analiz i Issled. operations. Ser. 2. - 2001. - Vol. 8, №. 1. - pp. 47-69.

7. Khusnutdinov R.I. Methylation of aniline and its derivatives with dimethyl carbonate in the presence of micro-, meso- and macroporous zeolites KNaX, NaY and Hy without a binder / R.I. Khusnutdinov, N.A. Shchadneva, Yu.Yu. Mayakova, S.I. Ardieva A.N. Khazipova, B.I. Kutepov // Journal of Organic Chemistry. 2016. - Vol. 52. -№ 11. - pp. 1574-157

8. Koledina, K. F. Automated System for Identification of Conditions for Homogeneous and Heterogeneous Reactions in Multiobjective Optimization Problems / K. F. Koledina, S. N. Koledin, I. M. Gubaydullin / Numerical Analysis and Applications. April 2019. - Vol. 12, Is. 2. - pp 116-125.

9. Deb, K. Towards a quick computation of well-spread Pareto-optimal solutions / K. Deb, M. Mohan, S. Mishra // Evolutionary Multi-Criterion Optimization. Springer. - 2003. - pp. 222-236.

10. Srinivas, N. Muiltiobjective optimization using nondominated sorting in genetic algorithms. / N.

Srinivas, K. Deb // Evolutionary computation. - 1994. - Vol 2 (3). - pp. 221 - 248.

11. Safiullina L.F., Sensitivity analysis of the mathematical model of catalytic reforming of gasoline / L.F. Safiullina, I. M. Gubaydullin, K. F. Koledina, R Z. Zaynullin // Computational mathematics and information technologies. - Vol. 2. -№ 2. -2019-pp. 43-53.

12. Zainullin R.Z., Multi-Criterion Optimization of a Catalytic Reforming Reactor Unit Using a Genetic Algorithm / R. Z. Zainullin, A. N. Zagoruiko, K. F. Koledina, I. M. Gubaidullin, and R. I. Faskhutdinova // Catalysis in Industry. - 2020. - Vol. 12. - №. 2. - pp. 133-140.

13. Zainullin, R. Z. Kinetics of the Catalytic Reforming of Gasoline / R. Z. Zainullin, K. F. Koledina, A. F. Akhmetov, I. M. Gubaidullin // Kinetics and Catalysis. - 2017. - Vol. - 58. - № 3. - pp. 279-289.

\section{Authors:}

Kamila F. Koledina, Cand.Sci. (Phys.-Math.), associate professor, researcher, associate professor of the Mathematics Department Institute of Petrochemistry and Catalysis of RAS, Ufa State Petroleum Technological University (Kosmonavtov St., Ufa, Russian Federation), koledinakamila @ mail.ru

Sergey N. Koledin, Ph.Dr. (Phys.-Math.), associate professor of the Mathematics Department, Ufa State Petroleum Technological University (Kosmonavtov St., Ufa, Russian Federation), koledinsrg @gmail.com

Irek M. Gubaydullin, Dr.Sci. (Phys.-Math.), associate professor, senior researcher, professor of the Oil and Gas Technology Department, Institute of Petrochemistry and Catalysis of RAS, Ufa State Petroleum Technological University (Kosmonavtov St., Ufa, Russian Federation), IrekMars@ mail.ru 


\title{
Алгоритм анализа устойчивости решения многокритериальной оптимизации каталитических процессов к малым возмущениям в параметрах, через кинетическую модель *
}

\author{
К.Ф. Коледина ${ }^{1,2}$, С.Н. Коледин ${ }^{2}$, И.М. Губайдуллин ${ }^{1,2 * *}$ \\ ${ }^{1}$ Институт нефтехимии и катализа УФИЦ РАН, г. Уфа, Российская Федерация \\ 2 Уфимский государственный нефтяной технический университет, г. Уфа, Российская \\ Федерация
}

Многокритериальное оптимальное управление сложными каталитическими реакциями на основе кинетической модели актуально как для промышленных, так и лабораторных процессов. Для задач химической кинетики при анализе устойчивости многокритериальной оптимизации необходимо определить радиус устойчивости по каждому параметру, с целью возможного изменения рассчитанных значений с заданной погрешностью.

Приведена постановка задачи многокритериальной оптимизации (МКО) условий проведения каталитической реакции на основе кинетической модели. Дано определение устойчивости решения задачи МКО и радиуса устойчивости.

Разработан алгоритм расчета радиуса устойчивости решения МКО-задачи. Для каталитической реакции метилирования первичных аминов диметилкарбонатом решена задача МКО условий проведения на основе кинетической модели и рассчитан допустимый интервал изменения оптимальных значений температуры и времени реакции для недопущения сильного изменения значений критериев оптимальности.

Многокритериальное оптимальное управление сложными каталитическими реакциями на основе кинетической модели актуально как для промышленных, так и лабораторных процессов. Однако, является недостаточным только расчет всех эффективных траекторий, значений варьируемых параметров и критериев оптимальности. Для применения на практике рассчитанных режимов для лица принимающие решение (ЛПР) важным является информация о допустимом интервале изменения оптимальных режимов. В работе для каталитической реакции метилирования первичных аминов диметилкарбонатом решена задача МКО условий проведения на основе кинетической модели и рассчитан допустимый интервал изменения оптимальных значений температуры и времени реакции для недопущения сильного изменения значений критериев оптимальности.

Keywords: многокритериальная оптимизация, алгоритм расчета радиуса устойчивости, эффективные траектории, критерии оптимальности, варьируемые параметры, матрица возмущений, реакция метилирования аминов.

\footnotetext{
* Исследование выполнено за счет гранта Российского научного фонда (проект № 19-71-00006, п. 2,3), частичной финансовой поддержке гранта РФФИ № 18-07-00341.

**E-mail: koledinakamila@mail.ru, koledinsrg@gmail.com, IrekMars@mail.ru.
} 


\section{Авторы:}

Камила Коледина, кандидат физико-математических наук, доцент кафедры математики Уфимского государственного нефтяного технологического университета (ул. Космонавтов, 1, Уфа, Российская Федерация)

Сергей Коледин, кандидат физико-математических наук, доцент кафедры математики Уфимский государственный нефтяной технический университет (ул. Космонавтов, 1, Уфа, Российская Федерация), koledinsrg@gmail.com

Ирек Губайдуллин, доктор физико-математических наук, профессор кафедры технологии нефти и газа, Уфимский государственный нефтяной технический университет (ул. Космонавтов, 1, Уфа, Российская Федерация) 